\title{
Association between reproductive traits and four microsatellites in Brangus-lbagé cattle
}

\author{
João F.C. de Oliveira ${ }^{1,2}$, Jairo P. Neves1, Eric A. Almeida ${ }^{2}$, Clara Sabina Steigleder ${ }^{2}$, \\ José Carlos F. Moraes ${ }^{3}$, Paulo Bayard D. Gonçalves ${ }^{1}$ and Tania A. Weimer ${ }^{2,4}$ \\ ${ }^{1}$ Universidade Federal de Santa Maria, Departamento de Clínica de Grandes Animais, Laboratório de \\ Biotecnologia e Reprodução Animal, Santa Maria, RS, Brazil. \\ ${ }^{2}$ Universidade Federal do Rio Grande do Sul, Departamento de Genética, Porto Alegre, RS, Brazil. \\ ${ }^{3}$ Embrapa Pecuária Sul, Bagé, RS, Brazil. \\ ${ }^{4}$ Universidade Luterana do Brasil, Departamento de Biologia e Hospital Veterinário, Canoas, RS, Brazil.
}

\begin{abstract}
The aim of the present study was to verify associations between reproductive efficiency and four microsatellite markers located in synteny with genes involved in the regulation of reproductive mechanisms. A sample of 107 females from a Brangus Ibagé population (5/8 Aberdeen Angus x 3/8 Nelore) was characterized for ETH225 (D9S1) and MM12E6 (D9S20) microsatellites, mapped on chromosome 9, and HEL5 (D21S15) and AFZ1 (D21S37) on chromosome 21. Associations between the genetic markers and reproductive efficiency were determined by one-way analysis of variance using calving interval $(\mathrm{Cl})$, live weight at calving $(\mathrm{LWC})$, live weight at first calving (LW1C) and live weight at second calving (LW2C) as dependent variables. The genotypes were classified according to allele size into homozygous for long alleles, homozygous for short alleles and heterozygous. A longer $\mathrm{Cl}$ was observed for individuals homozygous for long alleles at the HEL5 locus compared with the others $(p=0.022)$. For the AFZ1 locus, an inverse correlation between allele size and calving interval was observed ( $p=0.022)$, suggesting that homozygosity for long alleles at this microsatellite could be advantageous. Analysis of the combined effect of favorable genotypes at HEL5 and AFZ1 indicated that animals with unfavorable genotypes (homozygous for long alleles at HEL5 and homozygous for short alleles at AFZ1) presented a significantly longer $\mathrm{Cl}(p=0.003)$ when compared to the other genotypes. The ETH225 and MM12E6 systems did not present any association with $\mathrm{Cl}$. None of the systems studied showed any significant association with LWC, LW1C or LW2C.
\end{abstract}

Key words: bovine, IGF-I receptor, estrogen receptor, reproductive efficiency.

Received: February 20, 2004; Accepted: June 25, 2004.

\section{Introduction}

Microsatellite markers are particularly useful due to their wide variability, random distribution throughout the genome, Mendelian inheritance (Tautz 1993) and possible influence on gene regulation (Schroth et al. 1992; Comings 1998). Microsatellites tend to be concentrated in transcription initiation regions, with the virtual absence of these sequences at intergene positions and in pseudogenes. Sequences rich in alternating purines and pyrimidines, (CA)n, such as microsatellites, are able to form Z-DNA under physiological conditions (Comings 1998). These facts suggest the potential role of microsatellites in gene regula-

Send correspondence to João Francisco Coelho de Oliveira. Universidade Federal de Santa Maria, Departamento de Clínica de Grandes Animais, Laboratório de Biotecnologia e Reprodução Animal, 97105-900 Santa Maria, RS, Brazil. E-mail: joaofco@ biorep. ufsm.br. tion. Based on these considerations, the association between a microsatellite and a given polygenic phenotype would be not dependant on a specific allele but on a repeat size threshold.

In a study on a Brangus Ibagé cattle population involving individuals with different degrees of fertility, Oliveira et al. (2002b) observed differences in the postpartum follicular development. The mean diameter of the larger follicles and the mean number of follicles were larger in individuals with greater reproductive efficiency, suggesting that mechanisms related to post-partum follicular development were important in the classification of individuals when mean calving interval was used as a criterion. Studies conducted on various species have demonstrated that estrogen plays an important role on follicular development, including follicle stimulation and maturation (Goldenberg et al. 1972) and the increased expression of 
follicle-stimulating hormone and luteinizing hormone receptors by granulosa cells (Richards et al. 1976; Richards et al. 1979). In cattle, the dominant follicle presents higher estrogen levels than follicles entering in atresia (Evans and Fortune 1997). Evidence also indicates that the insulin-like growth factor (IGF) system consisting of IGF-I and -II, IGF receptors and IGF-binding proteins (IGFBP) is important for the modulation of the effect of nutrition on post-partum anestrus (Monget and Martin 1997; Constant et al. 2000). Thus, estrogen and IGF-I receptors can be considered good candidates for the study of the possible association between molecular markers and reproductive efficiency.

The present study analyzed the possible association between genetic markers and reproductive efficiency through four microsatellite loci located on the same chromosome as the estrogen receptor and IGF-IR genes.

\section{Materials and Methods}

Four microsatellites [ETH225 (D9S1), MM12E6 (D9S20), HEL5 (D21S15) and AFZ1 (D21S37)] were investigated. The first two are located on BTA9 chromosome, the same of the estrogen receptor gene (ESR1), ETH225 at $8 \mathrm{cM}, \mathrm{MM} 12$ at about $77 \mathrm{cM}$, and ESR1 at $9 \mathrm{cM}$. The other two are located on the BTA21 chromosome which contains the IGF-IR gene, HEL5 at $13 \mathrm{cM}$, AFZ1 at $75 \mathrm{cM}$ and the IGF1-R locus at $0 \mathrm{cM}$ from AFZ1. (Barendse et al. 1997; http://www.ncbi.nlm.nih.gov; http://www. marc.usda.gov; http://www.inra.fr).

The association with reproductive efficiency was tested in a sample of 107 individuals obtained from a Brangus Ibagé herd originating from Embrapa, Pecuária Sul, Bagé, RS, Brazil, previously classified according to the average of their calving interval records, (Oliveira, 2002a). The following parameters were used: calving interval, live weight at calving (LWC), live weight at first calving (LW1C) and live weight at second calving (LW2C). This population has been formed since 1945 , its genetic proportion being fixed at 3/8 Nelore x 5/8 Aberdeen Angus. The herd was solely selected according to male adult weight and female size (Oliveira et al. 1998), not suffering any selection based on reproductive efficiency. All individuals of the sample possessed reproductive records for at least three calving and had always been managed on a native field.
Genomic DNA was extracted from blood collected by puncture of the jugular vein using an anticoagulant according to the method of Plante et al. (1992). Microsatellite fragments were amplified by the polymerase chain reaction (PCR) according to Stone et al. (1996) using adjacent primers and annealing temperature specific for each fragment (Table 1). The amplified fragments were separated by vertical non-denaturing polyacrylamide gel electrophoresis with $30 \mathrm{~cm}$ of height colored with Ethidium Bromide (Lahiri et al. 1997). The final characterization of each allele was performed using pBR322 plasmid digested with restriction enzymes as molecular weight markers. The size of each fragment was determined on digital photographs using the Kodak Digital Science 1D Analysis Software.

Linkage disequilibrium between loci considering individual alleles was tested by the maximum likelihood ratio using the Arlequin program (Schneider et al. 2000). Associations analyses between genotype classes of genetic markers and reproductive performance were determined by one-way analysis of variance, considering the genotype classes of the alleles as independent variables and reproductive records measurements as dependant variables. Calving interval data were normalized using a natural logarithm, and LWC data were analyzed without transformation since they showed a normal distribution. The genotypes were grouped according to allele size into the following classes: homozygous for short alleles, homozygous for long alleles and heterozygous.

\section{Results}

The number of individuals, the observed alleles, and the frequencies of genotypes grouped in classes according to the allele size of the four systems are shown in Table 2. There was a slight difference in the number of individuals studied per system due to amplification problems of some samples. Total heterozygosity was similar for the four systems, varying from 0.79 to 0.90 . Markers on chromosome 21 (AFZ1 and HEL5) were in linkage disequilibrium $(\mathrm{p}=0.04)$ but ETH225 and MM12 seem to segregate independently, as expected based on their chromosome distance.

For the HEL5 locus (Table 3 and Figure 1), homozygous for long alleles showed a trend towards a longer calv-

Table 1 - Investigated loci with their chromosome location, primer sequences and annealing temperature.

\begin{tabular}{lccc}
\hline Loci & Chromosome & Primers & Annealing temperature $\left({ }^{\circ} \mathrm{C}\right)$ \\
\hline HEL5 & 21 & $\begin{array}{l}\text { 5'-GCAGGATCACTTGTTAGGGA-3' } \\
\text { 5'-AGACGTTAGTGTACATTAAC-3' }\end{array}$ & 60 \\
AFZ1 & 21 & $\begin{array}{l}\text { 5'-TTGGACGACAAAACTCACGG-3' } \\
\text { 5'-GTGGCTGGACTGGTCTGGTT-3' }\end{array}$ & 50 \\
ETH225 & 9 & $\begin{array}{l}\text { 5'-GATCACCTTGCCACTATTTCCT-3' } \\
\text { 5'-ACATGACAGCCAGCTGCTACT-3' }\end{array}$ & 60 \\
MM12 & 9 & $\begin{array}{l}\text { 5'-CAAGACAGGTGTTCAATCT-3' } \\
\text { 5'-ATCGACTCTGGGGATGATGT-3' }\end{array}$ & 50 \\
\hline
\end{tabular}


Table 2 - Number of animals, allele sizes and genotype frequencies of the individuals classified as homozygous for short (H. Short), homozygous for long (H. Long) and heterozygous.

\begin{tabular}{|c|c|c|c|c|c|c|c|}
\hline \multirow[t]{2}{*}{ Locus } & \multirow[t]{2}{*}{ Total alleles } & \multirow[t]{2}{*}{$\mathrm{N}$} & \multicolumn{2}{|c|}{ Allele size (bp) } & \multicolumn{3}{|c|}{ Genotype frequency } \\
\hline & & & Short & Long & H. short & H. long & Heterozygous \\
\hline HEL5 & 12 & 101 & $147-157$ & $159-169$ & 0.27 & 0.49 & 0.24 \\
\hline AFZ1 & 9 & 103 & $115-121$ & $123-129$ & 0.38 & 0.16 & 0.46 \\
\hline ETH225 & 11 & 105 & $139-149$ & $151-159$ & 0.27 & 0.49 & 0.24 \\
\hline MM12 & 9 & 106 & $117-127$ & $129-133$ & 0.25 & 0.20 & 0.55 \\
\hline
\end{tabular}

Table 3 - Results of association analyses between calving interval and microsatellite genotype classes homozygous for short (H. Short), homozygous for long (H. Long) and heterozygous.

\begin{tabular}{lccccccc}
\hline Locus & \multicolumn{7}{c}{ Calving interval (means \pm SE) } \\
\cline { 2 - 8 } & $\mathrm{n}$ & H. short & $\mathrm{n}$ & H. long & $\mathrm{n}$ & Heterozygous & $\mathrm{p}$ \\
\hline HEL5 & 27 & $522.23 \pm 27.1^{\mathrm{a}}$ & 50 & $569.16 \pm 17.90^{\mathrm{b}}$ & 24 & $509.06 \pm 20.28^{\mathrm{ab}}$ & 0.072 \\
AFZ1 & 39 & $574.17 \pm 22.5^{\mathrm{a}}$ & 17 & $489.47 \pm 18.60^{\mathrm{b}}$ & 47 & $540.43 \pm 17.96^{\mathrm{ab}}$ & 0.076 \\
ETH225 & 40 & $536.71 \pm 17.7$ & 15 & $563.68 \pm 38.88$ & 50 & $543.57 \pm 18.69$ & 0.853 \\
MM12 & 27 & $542.23 \pm 23.9$ & 21 & $577.25 \pm 32.33$ & 58 & $532.35 \pm 15.57$ & 0.407 \\
\hline
\end{tabular}

a, b, c Values with different superscript in the same row differ significantly $(\mathrm{p}<0.10)$.

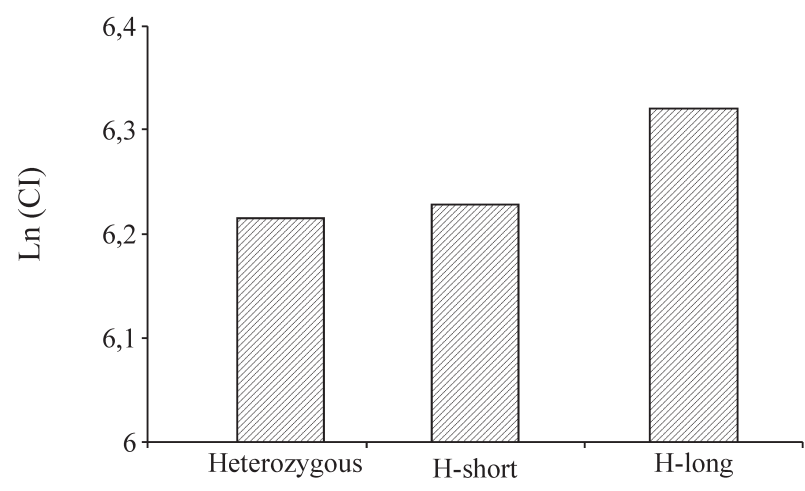

Genotype classes

Figure 1 - Natural logarithm of mean calving interval (CI) obtained from different genotype classes of the HEL5 locus grouped into homozygous for short alleles(H-short), homozygous for long alleles (H-log) and heterozygous. When homozygous for short alleles and heterozygous were grouped, the difference was significant $(\mathrm{p}=0.022)$.

ing interval compared with the other individuals $(p=0.072)$. Additional analysis grouping homozygotes for short alleles with heterozygotes and contrasting them with homozygotes for long alleles revealed a significant association $(p=0.022)$, suggesting an effect of long alleles on the prolonged calving interval.

At the AFZ1 locus, homozygous for long alleles presented shorter calving interval, homozygous for short alleles showed longer calving interval while heterozygotes had intermediate values $(\mathrm{p}=0.065$; Table 3$)$. Analysis of variance considering only homozygous individuals revealed an inverse correlation between allele size and calving interval $(p=0.022)$, suggesting that homozygosity for
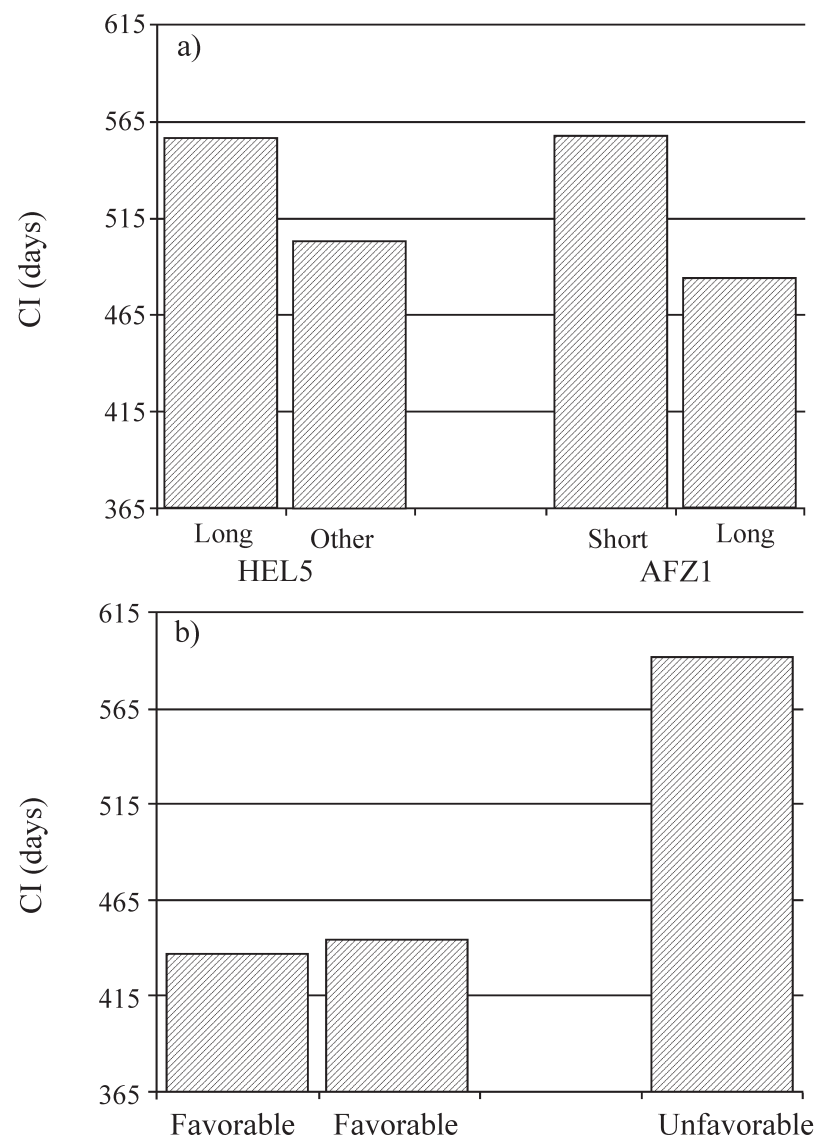

Figure 2 - Mean calving interval (CI; untransformed data) obtained from the different genotype classes of the HEL5 and AFZ1 microsatellites assessed independently (A). Panel B shows favorable (lower CI) and unfavorable (higher $\mathrm{CI}$ ) genotypes based on the combination of results obtained from both loci. 
long alleles at this microsatellite could be advantageous. Based on these results, we investigated the combined effect of these two microsatellites on calving interval. For this purpose, the genotypes were classified into favorable (individuals with at least a short allele at HEL5 and homozygous for long alleles at the AFZ1 locus) and unfavorable genotypes (individuals homozygous for long alleles at HEL5 and homozygous for short alleles at AFZ1). Statistical analysis comparing favorable and unfavorable genotypes with the other categories demonstrated highly significant associations $(\mathrm{p}=0.004$ and $\mathrm{p}=0.003$, respectively; Figure 2$)$.

With respect to LWC (Table 4), homozygous for long alleles at AFZ1 showed consistently a slightly higher LWC than the other individuals but the differences were not statistically significant. There were also no significant associations between LWC and HEL5, ETH225 and MM12E5 genotypes.

\section{Discussion}

The present study investigated possible associations between reproductive performance and loci selected based on the role of estrogen and IGF-I in the control of the regulation of folliculogenesis and the reinitiation of postpartum cyclicity in beef cattle.

The results indicated associations of AFZ1 and HEL5 markers mapped in synteny with the gene encoding IGF-IR on reproductive performance. The IGF system, consisting of IGF-I and -II, IGF-IR, and IGFBP, has been shown to be an important component of the mechanisms that coordinate ovarian follicular function in different species, including cattle (Spicer and Encternkamp 1995). The alterations in concentration and expression pattern of the IGF system components and their marked interference with growth and follicular dominance mechanisms may suggest a relevant influence of this system on regulation of the cyclicity reinitiation in cows after calving. The IGF-IR mRNA had been detected in theca interstitial and granulosa cells, with its levels increasing during the development of dominant follicles, suggesting its role in follicular development.

Suggestions that repetitive DNA sequences act on the regulation of gene expression are relatively recent but evidence is accumulating, especially for genes related to some human multifactorial diseases (Krontiris et al. 1993; Comings et al. 1996). The approach involving the establishment of allele classes for microsatellite loci proposed by Comings (1998), instead of considering the association with each allele, permits the inclusion of a larger number of individuals per genotype, thus increasing the reliability of association tests. Another aspect to be considered is the higher mutation rate observed for microsatellites compared to other sequences, as well as the type of mutation (stepwise) frequently observed in these repetitive DNA regions (Schlötterer, 1998). In view of these considerations, it is reasonable to suppose that genotypes of these systems that only differ in a small number of base pairs exert a similar effect on Quantitative Trait Locus (QTL). The results of the present study, using this approach permitted the detection of highly significant associations, validating the use of this

Table 4 - Results of association analyses between live weight at calving, live weight at first calving and live weight at second calving and the microsatellite genotype classes.

\begin{tabular}{|c|c|c|c|c|}
\hline \multirow[t]{2}{*}{ System } & \multicolumn{3}{|c|}{ Allele class } & \multirow[t]{2}{*}{$\mathrm{p}$} \\
\hline & H. short & Heterozygous & H. long & \\
\hline \multicolumn{5}{|c|}{ Live weight at calving } \\
\hline AFZ1 & $384.52 \pm 4.59$ & $391.57 \pm 4.29$ & $396.26 \pm 6.70$ & 0.30 \\
\hline ETH225 & $387.10 \pm 4.61$ & $394.73 \pm 4.05$ & $385.55 \pm 7.47$ & 0.36 \\
\hline HEL5 & $387.07 \pm 5.60$ & $398.35 \pm 5.93$ & $389.42 \pm 4.12$ & 0.34 \\
\hline MM12 & $397.63 \pm 5.63$ & $387.07 \pm 3.68$ & $388.30 \pm 6.36$ & 0.28 \\
\hline \multicolumn{5}{|c|}{ Live weight at 1 st calving } \\
\hline AFZ1 & $340.62 \pm 8.56$ & $347.11 \pm 7.97$ & $364.00 \pm 12.96$ & 0.33 \\
\hline ETH225 & $343.15 \pm 8.69$ & $360.62 \pm 7.68$ & $330.64 \pm 14.51$ & 0.12 \\
\hline HEL5 & $348.62 \pm 10.94$ & $357.83 \pm 11.63$ & $348.64 \pm 7.89$ & 0.79 \\
\hline MM12 & $349.30 \pm 10.64$ & $351.11 \pm 7.32$ & $348.45 \pm 12.37$ & 0.98 \\
\hline \multicolumn{5}{|c|}{ Live weight at 2 nd calving } \\
\hline AFZ1 & $392.82 \pm 11.19$ & $400.72 \pm 10.17$ & $405.71 \pm 16.73$ & 0.78 \\
\hline ETH225 & $399.73 \pm 10.87$ & $398.43 \pm 9.82$ & $398.07 \pm 18.37$ & 0.99 \\
\hline HEL5 & $383.15 \pm 13.40$ & $421.65 \pm 14.25$ & $396.58 \pm 9.66$ & 0.14 \\
\hline MM12 & $402.19 \pm 13.19$ & $394.42 \pm 9.08$ & $403.85 \pm 15.32$ & 0.82 \\
\hline
\end{tabular}

Data are reported as means \pm SE. 
method and representing a pioneering step towards marker-assisted selection in domestic animals.

According to Moody et al. (1996), the HEL5 locus is in linkage disequilibrium with the gene encoding IGF-IR which agrees with the linkage disequilibrium here verified between HEL5 and AZF1 since this last marker is at $0 \mathrm{cM}$ from IGF-IR. These data suggest that these microsatellites may be acting on the IGF-IR regulation or that their different allele classes are linked to alternative forms of this gene, resulting in a positive or negative effect on calving interval.

The estrogen receptor (E2R) gene is mapped on chromosome 9 , probably at $9 \mathrm{cM}$ (www.ncbi.nlm.nih.gov), but no reports of microsatellite markers associated with it have been described. Therefore, we chose markers randomly distributed along the chromosome, one close and the other far from it (at $8 \mathrm{cM}$ and $77 \mathrm{cM}$, respectively). Although estradiol plays a relevant role in the mechanisms of manifestation of follicular dominance and divergence, no association was observed with any of the systems studied.

The use of a more flexible probability level $(\mathrm{p}<0.10)$ for association studies involving multifactorial characteristics has been suggested by Haviland et al. (1997). In view of the small effect of each locus, a less rigid criterion prevents type 2 statistical errors. In the present study, only associations with a probability of less than 0.05 were considered to be significant, while a probability level of 0.10 was established as a previous criterion to perform the subsequent analyses, grouping of the allele in classes.

The associations observed in the present study indicate the possible utilization of favorable genotypes of the HEL5 and AFZ1 microsatellites in this population to increase reproductive efficiency. However, since the population studied here is a synthetic race, additional studies involving Bos Taurus and Bos indicus populations are necessary in order to determine whether the associations observed here can be extrapolated as a tool for markerassisted selection in beef cattle. Additionally, further investigations, using screening approaches such as SSCP or evaluation of previously described polymorphic markers in IGFI-R locus (Moody et al., 1996), are needed to understand possible modulatory effects involved in reproductive efficiency.

\section{Acknowledgements}

This study was funded by Programa de Apoio a Núcleos de Excelência (PRONEX), Financiadora de Estudos e Projetos (FINEP), Conselho Nacional de Desenvolvimento Científico e Tecnológico (CNPq), Fundação de Amparo a Pesquisa do Rio Grande do Sul - FAPERGS, and EMBRAPA/CPPSUL.

\section{References}

Barendse W, Vaiman D, Kemp SJ, Sugimoto Y, Armitage SM, Williams JL, Sun HS, Eggen A, Agaba M, Aleyasin SA,
Band M, Bishop MD, Buitkamp J, Byrne K, Collins F, Cooper L, Coppettiers W, Denys B, Drinkwater RD, Easterday K, Elduque C, Ennis S, Erhardt G, Ferretti L, Flavin N, Gao Q, Georges M, Gurung R, Harlizius B, Hawkins G, Hetzel J, Hirano T, Hulme D, Jorgensen C, Kessler M, Kirkpatrick BW, Konfortov B, Kostia S, Kuhn C, Lenstra JA, Leveziel H, Lewin HA, Leyhe B, Lil L, Burriel IM, Mcgraw RA, Miller JR, Moody DE, Moore SS, Nakane S, Nijman IJ, Olsaker I, Pomp D, Rando A, Ron M, Shalom AJ, Thieven $\mathrm{U}$, Urquhart BGD, Vage I, De Weghe AV, Varvio S, Velmala R, Vilkki J, Weikard R, Woodside C and Womack JE (1997) A medium-density genetic linkage map of the bovine genome. Mamm Genome 8:21-28.

Comings DE, Gade R, MacMurray JP, Muhleman D and Peters WR (1996) Genetic variants of the human obesity (OB) gene: Association with body mass index in young women, psychiatric symptoms, and interaction with the dopamine D-2 receptor (DRD2) gene. Molecular Psychiatry 1:325335 .

Comings DE (1998) Polygenic inheritance and micro/minisatellites. Molecular Psychiatry 3:21-31.

Constant F, Ponter AA, Ponsart C, Fontaine JJ, Mialot JP, Grimard B and Chastant, S (2000) Effect of underfeeding on plasmatic and intrafollicular IGF-BPs in post-partum anoestrus beef cows. Journal of Reproduction and Fertility (Abstract Series):15.

Evans ACO and Fortune JE (1997) Selection of the dominant follicle in cattle occurs in the absence of differences in the expression of messenger ribonucleic acid for gonadotropin receptors. Endocrinology 138:2963-2971.

Goldenberg RL, Vaitukaitis JL and Ross GT (1972) Estrogen and follicle stimulating hormone interactions on follicle growth in rats. Endocrinology 90:1492-1498.

Haviland MB, Ferrell RE and Sing CF (1997) Association between common alleles of the low-density lipoprotein receptor gene region and interindividual variation in plasma lipid and apolipoprotein levels in a population-based sample from Rochester, Minnesota. Human Genetics 99:108-114.

Krontiris TG, Devlin B, Karp DD, Robert NJ and Risch N (1993) An association between the risk of cancer and mutations in the HRAS1 minisatellite locus. New England Journal of Medicine 329:517-523.

Lahiri DK, Zhang AW and Nurnberger JI (1997) High-resolution detection of PCR products from a microsatellite marker using a nonradioisotopic technique. Biochemical and Molecular Medicine 60:70-75.

Monget P and Martin GB (1997) Involvement of insulin-like growth factors in the interactions between nutrition and reproduction in female mammals. Hum Reprod 12 Suppl $1: 33-52$.

Moody DE, Pomp D and Barendse W (1996) Linkage mapping of the bovine insulin-like growth factor-1 receptor gene. Mammalian Genome 7:168-169.

Oliveira NM, Salomoni E, Leal JJB, Moraes JCF and Del Duca LOA (1998) Genetic and environmental effects on growth of $3 / 8$ Nelore x 5/8 Aberdeen Angus beef cattle derived from different crossbreeding schemes. Archivos Latinoamericanos de Producción Anima 6:173-188.

Oliveira JFC, Neves JP, Moraes JCF and Gonçalves PBD (2002a) Characterization of productive aspects in Brangus lbage 
cows with distinct levels of fertility. Ciencia Rural 32:663-667.

Oliveira JFC, Neves JP, Moraes JCF, Gonçalves PBD, Barr JM, Hernandez AGV and Bonotto G (2002b) Follicular population and steroid levels in Brangus Ibagé with distinct levels of fertility. Animal Reproduction Science 73:1-10

Plante Y, Schmutz SM and Lang KDM (1992) Restriction fragment length polymorphism in the mitochondrial DNA of cloned cattle. Theriogenology 38:887-904.

Richards JS, Ireland JJ, Rao MC, Bernath GA, Midgley AR and Reichert LE (1976) Ovarian follicular development in rat hormone receptor regulation by estradiol, Follicle Stimulating Hormone and Luteinizing Hormone. Endocrinology 99:1562-1570.

Richards JS, Jonassen JA, Rolfes AI, Kersey K and Reichert LE (1979) Adenosine-3',5'-monophosphate, luteinizing hormone receptor, and progesterone during granulosa cell differentiation - Effects of estradiol and follicle stimulating hormone. Endocrinology 104:765-773.

Schlötterer C (1998) Microsatellites, In: Hoelzel AR (ed), Molecular Genetic Analysis of Populations: A Practical Approach. Oxford University Press, New York, pp 237-261.
Schneider S, Roessli D and Excoffier L (2000) Arlequin ver. 2.000: A software for population genetics data analysis, Genetics and Byometry Laboratory, University of Geneva, Switzerland, pp 1-111.

Schroth GP, Chou PJ and Ho PS (1992) Mapping Z-DNA in the human genome - Computer-aided mapping reveals a nonrandom distribution of potential Z-DNA forming sequences in human genes. Journal of Biological Chemistry 267:11846-11855.

Spicer LJ and Encternkamp SE (1995) The ovarian insulin and insulin-like growth factor system with an emphasis on domestic animals. Domestic Animal Endocrinology 12:223-245.

Stone RT, Kappes SM and Beattie CW (1996) Five polymorphic trinucleotide (CCA) bovine microsatellites. Animal Genetics 27:216.

Tautz D (1993) Notes on the definition and nomenclature of tandemly repetitive DNA sequences, In: Pena SDJ, Chakraborty JT, Epplen JT and Jeffreys AJ (eds), DNA Fingerprinting: State of the Science. Birkhäuser Verlag Basel, Switzerland, pp 21-28.

Associate Editor: Pedro Franklin Barbosa 